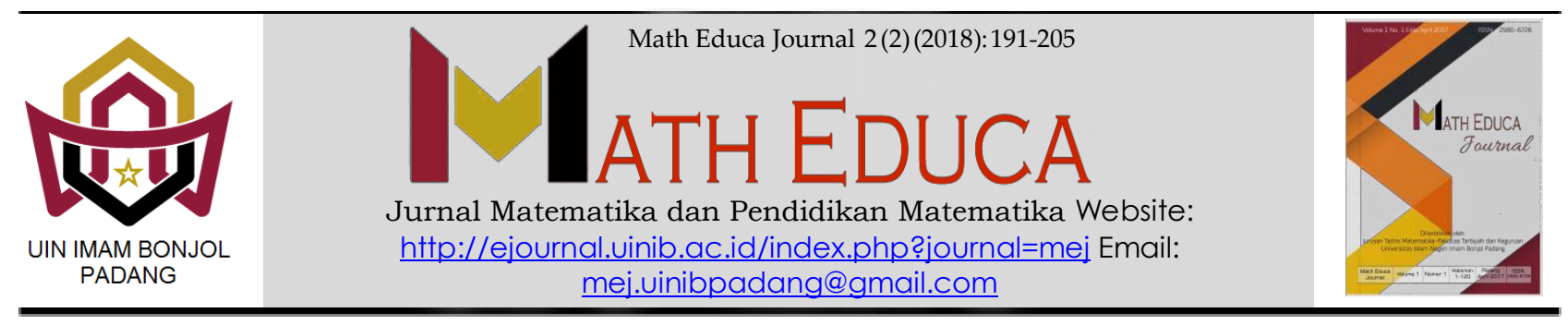

\title{
Perbedaan Hasil Belajar Matematika Siswa Menggunakan Strategi Active Learning Dengan Cara Giving Questions And Getting Answers Dengan Pembelajaran Konvensional Di Kelas X Sma Ekasakti Padang
}

\author{
Yuliani Fitri', Refnywidialistuti² \\ 1,2Program Studi Pendidikan Matematika, FKIP, Universitas Ekasakti Padang, Indonesia \\ Email: 1 Yulianifitri020784@gmail.com, ${ }^{2}$ refnywidia@gmail.com
}

Received: Agustus 2018; Accepted: September 2018; Published: Oktober 2018

\begin{abstract}
Abstrak
Jenis penelitian ini berbentuk eksperimen, yaitu eksperimen yang dilaksanakan pada dua kelompok yaitu kelompok eksperimen dan kelompok kontrol. Tujuan dari penelitian ini adalah untuk mengetahui apakah hasil belajar matematika siswa yang menggunakan strategi active learning dengan cara giving questions and getting answers lebih baik daripada menggunakan pembelajaran konvensional. Adapun manfaat dari penelitian ini adalah sebagai pedoman bagi peneliti dalam mengajar nanti dan sebagai masukan bagi Guru dalam pembelajaran matematika. Populasi dari penelitian ini adalah seluruh kelas X SMA Ekasakti TP 2017/2018 Padang yang terdiri dari 3 kelas. Sampelnya diambil kelas $X_{I S 1}$ sebagai kelas kontrol yang berjumlah 22 orang dan kelas $\mathrm{X}_{\mathrm{IS} 2}$ sebagai kelas eksperimen berjumlah 22 orang juga. Data diperoleh melalui tes hasil belajar yang diberikan kepada kelas eksperimen dan kelas kontrol. Sebelum dilakukan uji hipotesis, data tersebut dilakukan uji normalitas dan homogenitas. Setelah dianalisis, hasil belajar siswa tersebut normal dan homogen. Berdasarkan analisis uji hipotesis dapat disimpulkan bahwa penerapan strategi active learning dengan cara giving questions and getting answers dapat meningkatkan hasil belajar matematika siswa pada taraf kepercayaan 95\%. Sesuai dengan hal tersebut, maka disarankan agar guru dapat menerapkan strategi active learning dengan cara giving questions and getting answers dalam proses pembelajaran matematika karena dapat meningkatkan hasil belajar matematika siswa.
\end{abstract}

Kata kunci: hasil belajar, active learning, Giving Questions and Getting Answers

\section{Abstract}

The study is a kind of experimental one conducted to two groups, an experimental group and controlled group. The purpose of the study was to figure out whether students' learning achievement by using giving questions and getting answers of active learning strategy better than those of conventional learning. The finding of the study is supposed to be useful for the researcher in teaching and to be guidance for teachers in mathematics learning.

Population of the study were all of the students grade X TP 2017/2018 of Eka Sakti Senior High School, consisting of three classes. The samples were $X_{I S_{1}}$ as the controlled class consistingof 22 students and $X_{I S_{2}}$ as the experimental class consisting of 22 students. Data collected by having a test to the experimental class and controlled class. Normality and homogeneity tests were conducted before doing hypothesis test. The students' learning achievement were normal and homogeny. Based on the analysis of hyphothesis tetsting, it can be concluded that

\footnotetext{
${ }^{*}$ Corresponding author.

Peer review under responsibility UIN Imam Bonjol Padang.

(C) 2018 UIN Imam Bonjol Padang. All rights reserved.

p-ISSN: 2580-6726

e-ISSN: 2598-2133
} 
application of active learning strategy by giving questions and getting answers can increase students' mathematics learning achievement for $95 \%$ level of realibility. Therefore, it is hopped that teachers will apply active learning strategy by giving questions and getting answers in teaching learning process of mathematics due to its significant effect to learning achievement of the students.

Keywords: learning achievement, active learning, giving questions and getting answers

\section{PENDAHULUAN}

Matematika merupakan mata pelajaran yang memegang peranan penting dalam perkembangan ilmu pengetahuan dan teknologi.

Oleh sebab itu, matematika diajarkan di setiap tingkatan sekolah mulai SD, SMP dan SMA. Matematika yang dipelajari di sekolah tersebut menjadi dasar untuk perkembangan pendidikan matematika selanjutnya karena materinya saling berkaitan satu sama lainnya. Apabila siswa sudah paham dengan konsep matematika yang didapatkan ketika sekolah dan bisa mengaplikasikannya dalam mengerjakan soal-soal yang berhubungan dengan konsep tersebut, maka siswa tersebut akan mudah dalam memahami konsep matematika selanjutnya.

Tujuan pengajaran matematika agar siswa dapat berpikir logis, kritis, cermat dan disiplin. Selain itu, agar siswa dapat mengasah otaknya agar mereka bisa mengembangkan potensi yang tersimpan dalam dirinya sehingga dapat memunculkan ide-ide kreatif yang bisa menghasilkan berbagai inovasi. Oleh sebab itu, kita mengharapkan proses pembelajaran matematika di masing-masing sekolah bisa berjalan dengan baik dengan cara melibatkan siswa secara aktif dalam proses belajar mengajar agar memberikan hasil yang memuaskan.

Namun, pada kenyataannya siswa masih kurang aktif dalam proses pembelajaran matematika. Siswa lebih banyak menerima materi dari guru ketika baru belajar di sekolah. Selain itu, siswa juga mempunyai anggapan bahwa matematika merupakan salah satu pelajaran yang cukup sulit, sehingga matematika termasuk salah satu pelajaran yang kurang disukai. Rumus dengan segala macam perhitungan yang cukup rumit sering menyebabkan siswa menyerah di tengah jalan dan kurang berminat untuk menekuninya, akibatnya aktivitas belajar siswa belum begitu aktif dan hal ini secara tidak langsung akan mempengaruhi hasil belajar siswa, yang mana hasil yang diperoleh belum mencapai kriteria ketuntasan minimal di sekolah tersebut yaitu 76.

Untuk mengatasi masalah tersebut maka seorang guru berusaha agar siswanya lebih aktif lagi dalam belajar sehingga hasil belajarnya dapat tercapai sesuai dengan yang diinginkan. Salah satu usaha yang digunakan dalam pembelajaran matematika adalah pembelajaran aktif dengan cara memberikan 
pertanyaan dan mendapatkan jawaban atau bahasa lainnya "giving questions and getting answers" . Dalam pendekatan ini siswa dituntut untuk lebih aktif dalam proses belajar mengajar, menanyakan materi yang belum mereka pahami dan menjelaskan materi yang sudah dimengerti kepada teman-teman sekelasnya. Dengan demikian hal tersebut akan berdampak terhadap hasil belajarnya.

Secara umum masalah yang dapat diidentifikasi adalah:

1. Hasil belajar matematika siswa belum mencapai target yang diinginkan

2. Kurangnya motivasi siswa dalam proses pembelajaran

3. Siswa kurang aktif dalam belajar

4. Kurangnya respon siswa menyampaikan secara langsung materi-materi yang belum mereka pahami atau menanyakan materi yang belum dimengerti.

5. Kurangnya respon siswa menerangkan materi yang dipahaminya kepada teman sekelasnya.

Karena keterbatasan kemampuan yang penulis miliki, maka tidak semua masalah yang teridentifikasi dapat dipecahkan. Berdasarkan identifikasi masalah yang dikemukakan di atas, maka penulis mencoba mengatasi masalah pada nomor 1 dan 4 dengan menggunakan strategi active learning dengan cara giving questions and getting answers.

Berdasarkan latar belakang masalah yang dikemukakan di atas, maka rumusan masalah penelitian ini adalah "apakah hasil belajar matematika siswa yang menggunakan strategi active learning dengan cara giving questions and getting answesr lebih baik daripada menggunakan pembelajaran konvensional?"

Adapun tujuan penelitian ini adalah untuk mengetahui apakah hasil belajar matematika siswa yang menggunakan strategi active learning dengan cara giving questions and getting answers lebih baik daripada menggunakan pembelajaran konvensional.

Sebelum kita berbicara lebih jauh tentu kita perlu mengetahui apa itu pembelajaran aktif. Pembelajaran aktif adalah suatu pembelajaran yang mengajak siswa untuk belajar secara aktif. Ketika siswa belajar dengan aktif, berarti mereka yang mendominasi aktivitas pembelajaran.

Pada umumnya guru berbicara dengan kecepatan 100 hingga 200 kata permenit. Tetapi berapa banyak kata-kata yang dapat ditangkap siswa dalam permenitnya? Ini tentunya juga bergantung pada cara mereka mendengarkannya. Jika siswa benar-benar berkonsentrasi, mereka akan dapat mendengarkan dengan penuh perhatian terhadap 50 hingga 100 kat per menit, atau setengah dari apa yang dikatakan guru. Itu juga siswa berpikir banyak ketika guru menerangkan.

Alasan-alasan mengapa diterapkan belajar aktif supaya siswa mendapatkan hasil 
belajar yang maksimum. Ketika siswa pasif, atau hanya menerima dari guru, ada kecendrungan untuk cepat melupakan apa yang telah diberikan. Oleh sebab itu, diperlukan perangkat tertentu untuk dapat dapat mengikat informasi yang baru saja diterima dari guru. Belajar aktif adalah salah satu cara untuk mengikat informasi yang baru kemudian menyimpannya dalam otak.(Hisyam Zaini dkk, 2005 : xvii-xviii)

Lebih dari 2400 tahun silam, Konfusius menyatakan : Yang saya dengar saya lupa, yang saya lihat saya ingat, yang saya kerjakan saya pahami. Tiga pernyataan sederhana ini berbicara banyak tentang perlunya cara belajar aktif.(Melvin L Siberman, 2006 : 23)

Salah satu strategi belajar aktif yang akan dibahas adalah dengan cara memberikan pertanyaan dan mendapatkan jawaban atau giving questions and getting answers. Strategi ini sangat baik digunakan untuk melibatkan siswa dalam mengulang materi pelajaran yang telah disampaikan.

Pada strategi ini terdapat prinsipprinsip yang ada dalam al-Qur'an, seperti prinsip partisipasi aktif. Pada prinsip ini dituntut bagi orang yang belajar agar ikut berpartisipasi aktif dalam pembelajaran. Pada strategi active learning ini, siswa memang dituntut untuk aktif dalam pembelajaran. Hal ini sudah terbukti oleh para ahli, bagi mereka yang menerapkan active learning hasil belajar yang diperoleh lebih meningkat daripada pembelajaran yang dilakukan dengan sistem ceramah.

Pada strategi active learning ini, siswa dibagi ke dalam beberapa kelompok yang masing-masingnya terdiri dari empat atau lima orang. Pada kelompok terjadi saling kerja sama dalam membahas pertanyaan-pertanyaan yang muncul diantara mereka dan mengungkapkan materi-materi yang mereka pahami. Jadi, strategi active learning yang akan diterapkan tepat digunakan karena dalam proses pembelajaran terjadi kerjasama antara individu yang bertujuan untuk mendapatkan ilmu. Langkah-langkah dalam menerapkan giving questions and getting answers yaitu:

1. Buat potongan-potongan kertas sebanyak dua kali jumlah siswa

2. Setiap siswa diminta untuk melengkapi pernyataan berikut ini:

Kertas 1 : Saya masih belum paham tentang.........

Kertas 2 : Saya dapat menjelaskan tentang.........

3. Bagi siswa ke dalam kelompok kecil, 4 atau 5 orang.

4. Masing-masing kelompok memilih pertanyaan-pertanyaan yang ada (kartu 1), dan juga topik-topik yang dapat mereka jelaskan (kertas 2)

5. Minta setiap kelompok untuk membacakan pertanyaan-pertanyaan yang telah mereka seleksi. Jika ada diantara siswa yang bisa menjawab, diberi 
kesempatan untuk menjawab. Jika tidak ada yang bisa menjawab, guru harus menjawab.

6. Setiap kelompok diminta untuk menyampaikan apa yang dapat mereka jelaskan dari kertas 2. Selanjutnya minta mereka untuk menyampaikannya ke kawan-kawan.

7. Lanjutkan proses ini sesuai dengan waktu dan kondisi yang ada.

8. Akhiri pembelajaran dengan menyampaikan rangkuman dan klarifikasi dari jawaban-jawaban dan penjelasan siswa.(Hisyam Zaini dkk, 2005 : 70)

Penelitian yang relevan dengan penulis lakukan adalah penelitian yang dilakukan oleh Endar Madesa, UNP tahun 2003. Penelitian ini dilakukan terhadap siswa SMA 10 Padang dengan menggunakan strategi active learning tipe giving questions and getting answers yang diberikan pada kelas eksperimen sedangkan pada kelas kontrol hanya pembelajaran biasa. Dalam memberikan penilaian diberikan postes dengan soal yang sama. Kelas eksperimen memiliki hasil belajar yang lebih baik daripada kelas kontrol.

Penulis melakukan penelitian ini masih menggunakan strategi active learning dengan cara giving questions and getting answers. Perlakuan yang diberikan masih sama pada penelitian sebelumnya yang menggunakan kelas eksperimen dan kelas kontrol. Perbedaan penelitian tersebut dengan penulis lakukan adalah terletak pada lingkungan sekolah. Penelitian sebelumnya dilaksanakan pada SMAN 10 Padang kelas $\mathrm{X}$ semester 2, sedangkan penelitian yang dilakukan penulis di SMA Ekasakti Padang kelas X semester 2.

\section{METODE PENELITIAN}

\section{Jenis Penelitian}

Sesuai dengan permasalahan dan tujuan penelitian yang telah dikemukakan, jenis penelitian ini bersifat eksperimen. Penelitian ini menggunakan rancangan "The Static Group Comparison : Randomized Control Group Only Design"(Suryabrata, 2003:104) yaitu eksperimen yang dilakasanakan pada dua kelompok, yaitu kelompok eksperimen dan kelompok kontrol. Kelompok eksperimen dikenal variabel perlakuan tertentu dalam tertentu, lalu kedua kelompok itu dikenal pengukuran yang sama. Perbedaan yang timbul dianggap bersumber pada variabel perlakuan. Bagan rancangan penelitian ini dapat digambarkan sebagai berikut:

Tabel 1. Rancangan Penelitian

\begin{tabular}{|l|c|c|c|}
\hline & Pretest & Treatment & Postest \\
\hline $\begin{array}{l}\text { Experiment } \\
\text { Group }\end{array}$ & & $\mathbf{X}$ & $\mathbf{T}_{2}$ \\
\hline $\begin{array}{l}\text { Control } \\
\text { Group }\end{array}$ & & & $\mathbf{T}_{2}$ \\
\hline
\end{tabular}

Keterangan :

$X=$ Perlakuan giving questions and getting answers

$\mathrm{T}_{2}=$ Tes setelah diberikan perlakuan 


\section{Populasi dan Sampel}

1. Populasi

Populasi adalah seluruh data yang menjadi perhatian kita dalam suatu ruang lingkup dan waktu yang kita tentukan (Margono, 1996). Pengertian lain menyebutkan bahwa populasi adalah keseluruhan objek penelitian. Jadi, populasi dalam penelitian ini adalah seluruh siswa kelas X SMA Ekasakti Padang yang terdaftar pada tahun pelajaran 2017/2018.

2. Sampel

Sampel adalah sumber data atau informasi yang dapat mewakili populasi. Sampel yang dipilih dalam penelitian haruslah representatif yang menggambarkan keseluruhan karakteristik dari suatu populasi. Sesuai dengan masalah yang diteliti dan metode penelitian yang digunakan, maka sampel dalam penelitian ini adalah dua kelas yaitu kelas kontrol dan kelas eksperimen.

Teknik pengambilan sampel adalah dengan cara random sampling (pengambilan data secara acak) dengan syarat anggota populasi harus homogen, sehingga harus dilakukan uji normalitas, uji homogenitas dan uji kesamaan rata-rata.

Penentuan sampel ini dilakukan dengan langkah-langkah sebagai berikut:

a. Mengumpulkan data nilai Ujian Akhir Semester 1 matematika siswa kelas $X$ Padang tahun pelajaran 2017/2018. b. Melakukan uji normalitas populasi bertujuan untuk melihat apakah populasi berdistribusi normal atau tidak. Uji normalitas dilakukan dengan menggunakan SPSS.

c. Uji Homogenitas variansi ini dilakukan untuk mengetahui apakah populasi mempunyai variansi yang homogen

Hipotesis yang diajukan:

$H_{0}=$ populasi mempunyai varian yang sama

$H_{1}=$ populasi mempunyai varian yang tidak sama

Dasar pengambilan keputusan

Jika $F_{\text {hitung }}<F_{\text {tabel }}$ atau probabilitasnya $>0,05$ maka $H_{0}$ diterima

Jika $F_{\text {hitung }}>F_{\text {tabel }}$ atau probabilitasnya $<0,05$ maka $H_{0}$ ditolak

\section{Prosedur Penelitian}

Secara umum prosedur penelitian ini dapat dibagi atas tiga bagian, yaitu: persiapan, pelaksanaan, dan penyelesaian.

1. Tahap Persiapan

1) Menentukan jadwal penelitian

2) Mempelajari materi matematika kelas $X$ SMA semester II

3) Mempersiapkan Rencana Pembelajaran (RPP). Setelah itu RPP diberikan kepada dosen/teman sejawat dan guru mata pelajaran matematika untuk divalidasi. Kegiatan ini untuk mengetahui apakah RPP sudah valid dan layak diberikan kepada siswa atau belum. 
4) Mempersiapkan hal-hal yang mendukung strategi belajar aktif dengan cara giving questions and getting answers seperti pembagian kelompok dan lembaran kertas pertanyaan dan jawaban. Kelompok dibagi berdasarkan kemampuan siswa yang dilihat dari data nilai ujian akhir semester ganjil matematika siswa kelas X tahun pelajaran 2017/2018, sehingga siswa terbagi secara proporsional. Artinya dalam satu kelompok terdapat siswa berkemampuan tinggi, sedang dan rendah.

5) Membuat kisi-kisi soal akhir

2. Mempersiapkan instrumen penelitian berupa soal tes akhir yang akan diberikan pada akhir pokok bahasan. Soal tes hasil belajar ini juga divalidasi pada dosen/teman sejawat dan seorang guru matematika

\section{Tahap Pelaksanaan}

1) Pada kelas eksperimen

Pada kelas eksperimen diterapkan strategi active learning dengan cara giving questions and getting answers dengan langkah sebagai berikut:

a. Guru membuka pelajaran dengan menyampaikan tujuan pembelajaran

b. Sebelum materi pelajaran disampaikan siswa dibagi menjadi kelompok kecil yang terdiri atas 4 atau 5 orang anggota. c. Lembaran kertas pertanyaan dan jawaban dibagikan kepada siswa dan siswa diminta melengkapi pernyataan yang ada di masing-masing kertas tersebut.

d. Setelah selesai, masing-masing kelompok membacakan pertanyaan atau hal-hal yang belum mereka mengerti yang telah dibuat pada kertas yang dibagikan. Kemudian diberi kesempatan pada kelompok lain untuk menjawab pertanyaan tersebut. Jika tidak ada siswa yang bisa menjawab maka guru yang menjawabnya.

e. Setiap kelompok disuruh menyampaikan materi atau hal-hal yang sudah dimengerti berdasarkan kertas jawaban yang telah dibagikan.

f. Lanjutkan proses ini sesuai dengan waktu dan kondisi yang ada

g. Akhiri pembelajaran dengan menyampaikan rangkuman dan klarifikasi dari jawaban-jawaban dan penjelasan siswa.

2) Pada Kelas Kontrol

Pada kelas kontrol diterapkan pembelajaran konvensional dengan langkah sebagai berikut:

a. Guru menyampaikan tujuan pembelajaran 
b. Guru menjelaskan materi secara klasikal dan tanya jawab mengenai materi yang diberikan.

3). Pada akhir pertemuan pada kelas eksperimen dan kelas kontrol diberikan tes untuk mengetahui hasil belajar kelas tersebut. Langkah-langkah dalam pemberian tes tersebut adalah sebagai berikut:

a. Melakukan uji coba tes

b. Tes akhir

c. Analisis Tes Akhir

\section{Instrumen Penelitian}

Instrumen penelitian yang digunakan dalam penelitian ini adalah tes. Untuk memperoleh data dalam penelitian ini, maka diberikan tes kepada kelompok eksperimen dan kelompok kontrol setelah diadakannya perlakuan. Soal yang diberikan sama kepada kelompok eksperimen dan kelompok kontrol.

Materi yang diujikan dalam tes sesuai dengan materi yang diberikan selama penelitian. Untuk mendapatkan tes yang baik dilakukan langkah-langkah sebagai berikut:

a. Membuat kisi-kisi tes.

b. Menyusun tes sesuai dengan kisi-kisi tes. Penyusunan tes dibuat berdasarkan kurikulum dan kompetensi dasar yang berkaitan dengan pokok bahasan .

c. Validasi Tes. Validasi yang digunakan dalam penelitian ini adalah validasi expert, di mana soal-soal tes diberikan kepada beberapa ahli. Dalam hal ini tes diberikan kepada beberapa dosen/teman sejawat dan seorang guru matematika.

d. Uji coba tes. Sebelum diberikan pada kelas sampel, terlebih dahulu dilakukan uji coba tes.

e. Analisis soal tes

Untuk mendapatkan soal yang baik, maka dilakukan langkah-langkah sebagai berikut:

1. Reliabilitas tes

Reliabilitas berhubungan dengan masalah kepercayaan. Suatu tes dapat dikatakan mempunyai taraf kepercayaan yang tinggi jika tes tersebut dapat memberikan hasil yang tetap.

Untuk menentukan indeks reliabilitas tes digunakan rumus alpha, menurut Arikunto (2006: 196) yaitu:

$$
\delta_{i}^{2}=\left[\frac{\sum x^{2}-\frac{\left(\sum x\right)^{2}}{N}}{N}\right] \quad r_{11}=\left[\frac{k}{k-1}\right]\left[1-\frac{\sum \delta_{b}^{2}}{\delta_{t}^{2}}\right]
$$

Keterangan:

$r_{11}=$ Reliabilitas tes

$\mathrm{k}=$ Banyak soal

$\sum \delta_{b}^{2}=$ Jumlah variansi skor setiap soal

$\delta_{t}^{2} \quad=$ Variansi total

Dengan kriteria harga $\mathrm{r}$ adalah

$0,80<r_{11} \leq 1,00$ reliabilitas sangat tinggi

$0,60<r_{11} \leq 0,80$ reliabilitas tinggi

$0,40<r_{11} \leq 0,60$ reliabilitas sedang 
$0,20<r_{11} \leq 0,40$ reliabilitas rendah

$0,00<r_{11} \leq 0,20$ reliabilitas sangat rendah

2. Daya Pembeda

Daya pembeda soal yaitu

kemampuan suatu soal untuk

membedakan antara siswa yang

mempunyai kemampuan yang rendah

dengan siswa yang berkemampuan tinggi.

Untuk menentukan daya pembeda butir

soal, digunakan rumus yang dikemukakan

oleh Dediknas (2001:28) adalah :

$\mathrm{DP}=($ mean kelompok atas - mean

kelompok bawah) : skor maksimum

soal

Dengan Kriteria :

$0,40 \leq \mathrm{DP} \leq 1,00$ : Soal diterima / baik

$0,30 \leq \mathrm{DP} \leq 0,39$ : Soal diterima

$0,20 \leq \mathrm{DP} \leq 0,29$ : Soal diperbaiki

$0,00 \leq \mathrm{DP} \leq 0,19$ : Soal tidak dipakai.

3. Indeks kesukaran

Untuk menentukan taraf kesukaran soal digunakan rumus seperti yang dikemukakan oleh Prawironegoro (1985:14) yaitu:

$I_{k}=\frac{D_{t}+D_{r}}{2 . m . n} \times 100 \%$

Soal dinyatakan sukar jika $I_{k}<27 \%$

Sedang jika $27 \% \leq I_{k} \leq 73 \%$

Mudah jika $\quad 7 \%<I_{k}$

\section{Teknik Analisis Data}

Untuk menarik kesimpulan, dilaksanakan pengujian hipotesis secara statistik. Adapun hipotesis secara statistik dari penelitian ini adalah:

$\mathrm{H}_{\mathrm{o}}$ : Hasil belajar matematika siswa yang menggunakan strategi active learning dengan cara giving questions and getting answers sama dengan menggunakan pembelajaran konvensional.

$\mathrm{H}_{1}$ : Hasil belajar matematika siswa yang menggunakan strategi active learning dengan cara giving questions and getting answers lebih baik daripada menggunakan pembelajaran konvensional.

Berdasarkan hipotesis statistik, maka perlu dilakukan analisis data, yaitu data tes hasil belajar antara kelas eksperimen dengan kelas kontrol. Nilai antara kelas eksperimen dan kelas kontrol dilakukan uji normalitas dan uji homogenitas data. Uji normalitas dan homogenitas dilakukan dengan menggunakan SPSS.

1. Uji Normalitas

Uji normalitas bertujuan untuk melihat apakah kedudukan skor tes hasil belajar kelas eksperimen dengan kelas kontrol berdistribusi normal atau tidak. Untuk melihat apakah data berdistribsi normal atau tidak, digunakan cara interpretasi P-value yaitu data berdistribusi normal jika P-value yang diperoleh lebih besar 
dari taraf nyata ( $\alpha$ ) yang telah ditetapkan yaitu 0,05, dan tidak normal jika sebaliknya.

2. Uji homogenitas

Uji homogenitas bertujuan untuk mengetahui apakah data tes hasil belajar kelas eksperimen dengan kelas kontrol mempunyai variansi yang homogen atau tidak. Untuk melihat apakah data homogen atau tidak, digunakan cara interpretasi P-value yaitu data homogen jika P-value yang diperoleh lebih besar dari taraf nyata (a) yang telah ditetapkan dan tidak homogen jika sebaliknya.

3. Uji hipotesis

Uji hipotesis ini bertujuan untuk membuktikan apakah hipotesis yang ditetapkan memang benar atau tidak, maksudnya apakah hasil belajar siswa kelas eksperimen lebih baik dari pada kelas kontrol. Berdasarkan hipotesis yang dikemukakan, maka dilakukan uji satu pihak dengan rumusan hipotesis

$$
H_{0}: \mu_{1}=\mu_{2} \quad H_{1}: \mu_{1}>\mu_{2}
$$

Dengan $\mu_{1} d_{a n} \mu_{2}$ masing-masing adalah hasil belajar matematika siswa pada kelas eksperimen dan kelas kontrol. Dari data tes akhir dilakukan uji normalitas dan homogenitas diperoleh hasil analisis yang telah didapatkan hasil tes akhir adalah nomal dan homogen, sehingga untuk uji kesamaan rata-rata digunakan rumus:

$$
\begin{aligned}
& t=\frac{\overline{X_{1}}-\overline{X_{2}}}{s \sqrt{\frac{1}{n_{1}}+\frac{1}{n_{2}}}} \\
& s^{2}=\frac{\left(n_{1}-1\right) s_{1}^{2}+\left(n_{2}-1\right) s_{2}^{2}}{n_{1}+n_{2}-2}
\end{aligned}
$$

Dengan :

$\overline{X_{1}} \quad=$ Skor rata-rata kelas eksperimen

$\overline{X_{2}} \quad=$ Skor rata-rata kelas kontrol

$\mathrm{s} \quad=$ Simpangan baku perbedaan rata-rata

$\mathrm{n}_{1} \quad=$ Jumlah siswa kelas eksperimen

$\mathrm{n}_{2}=$ Jumlah siswa kelas kontrol

$\mathrm{s}_{1}=$ Standar deviasi kelas eksperimen

$\mathrm{S}_{2}=$ Standar deviasi kelas kontrol

Kriteria pengujian adalah terima $\mathrm{H}_{0}$ jika $\mathrm{t}<\mathrm{t}_{(1-\alpha)}$ dimana $\mathrm{t}_{(1-\alpha)}$ didapat dari daftar ditribusi $t$ dengan derajat kebebasan $n_{1}+n_{2}-2$ dan peluang $(1-\alpha)$

\section{HASIL PENELITIAN DAN PEMBAHASAN}

Penelitian dilakukan pada kelas $\mathrm{X}_{\mathrm{IS} 1}$ dan $\mathrm{X}_{\mathrm{IS2}}$ semester genap tahun ajaran 2017/2018 pada materi trigonometri di SMA Ekasakti Padang mengenai perbedaan hasil belajar matematika siswa menggunakan strategi active learning dengan cara giving questions and getting answers dengan pembelajaran konvensional di kelas X SMA Ekasakti Padang. Instrumen yang digunakan adalah tes hasil belajar. Kemudian dilakukan uji normalitas dan homogenitas dengan bantuan SPSS. Setelah itu dilakukan uji hipotesis hasil belajar dengan pengujian rumus-t. 
Hasil belajar siswa digunakan untuk melihat perkembangan belajar siswa. Penilaian terhadap hasil belajar bertujuan untuk melihat kemajuan siswa dalam hal penguasaan materi yang telah dipelajari.

Berdasarkan pelaksanaan tes akhir, diperoleh data hasil belajar matematika siswa yang diberi strategi active learning dengan cara giving questions and getting answers dengan pembelajaran konvensional.

Pada data awal kelas eksperimen terdapat 22 orang siswa dan kelas kontrol 22 orang siswa juga, dan pada saat penelitian jumlah siswa masih tetap sama dengan data awal. Data yang diperoleh dicari nilai rata-rata, nilai tertinggi ( $x$ maks), nilai terendah (x min), dan standar deviasi (s). Hasil perhitungan dapat dilihat pada tabel dibawah ini.

Tabel 2. Hasil Analisis Data Tes Akhir

\begin{tabular}{|l|l|r|l|l|}
\hline \multicolumn{1}{|c|}{ Kelas } & \multicolumn{1}{c|}{$\mathbf{N}$} & $\bar{x}$ & \multicolumn{1}{c|}{$s^{2}$} & \multicolumn{1}{c|}{$\mathbf{S}$} \\
\hline Eksperimen & 22 & 81,7 & 72,1 & 8,5 \\
\hline Kontrol & 22 & 77,6 & 116,6 & 10,8 \\
\hline
\end{tabular}

Dari tabel dapat dilihat bahwa rata-rata kelas eksperimen yaitu 81,7 lebih tinggi dibanding nilai rata-rata kelas kontrol yang sama jumlah siswanya dengan kelas eksperimen. Variansi kelas eksperimen 72,1 lebih kecil dari kelas kontrol yang variansinya adalah 116,6. Artinya hasil belajar kelas eksperimen memiliki keragaman yang lebih kecil dari kelas kontrol. Standar deviasi kelas eksperimen yaitu 8,5 lebih kecil dibandingkan kelas kontrol yang mempunyai standar deviasi yaitu10,8.

Nilai maksimum hasil tes akhir antara kelas eksperimen dan kontrol sama yaitu 100 sedangkan nilai minimum kelas eksperimen yaitu 65 lebih tinggi dibandingkan kelas kontrol yaitu 52. Jumlah siswa yang tuntas belajar pada kelas eksperimen adalah 17 dari 22 orang sedangkan pada kelas kontrol 14 dari 22 orang, sehingga persentase ketuntasan belajar masing-masing kelas (eksperimen dan kontrol) berturut-turut adalah 77,3 \% dan 63,6 \%. Hal ini berarti hasil belajar kelas eksperimen lebih baik dibandingkan hasil belajar kelas kontrol. Data tes akhir yang diperoleh terlebih dahulu dianalisis dengan melakukan langkah sebagai berikut:

1. Uji Normalitas

Uji normalitas data hasil belajar matematika kelas sampel bertujuan untuk mengetahui apakah data berdistribusi normal atau tidak. Untuk mengetahuinya bisa didapatkan melalui program SPSS.

\section{Tabel 3. Uji Normalitas Kelas Kontrol}

\begin{tabular}{|r|r|r|r|r|r|r|r|}
\hline & $\begin{array}{r}\text { Kolmogorov } \\
\text {-Smirnov }\end{array}$ & & $\begin{array}{r}\text { Shapiro- } \\
\text { Wilk }\end{array}$ & & & \\
\hline & Statistic & df & Sig. Statistic & df & Sig. & \\
\hline Nilai & .128 & 22 & .129 & .968 & 37 & .345 & \\
\hline
\end{tabular}

Tabel 3. Uji Normalitas Kelas Eksperimen

\begin{tabular}{|r|r|r|r|r|r|r|r|}
\hline & $\begin{array}{r}\text { Kolmogorov } \\
\text {-Smirnov }\end{array}$ & & $\begin{array}{r}\text { Shapiro- } \\
\text { Wilk }\end{array}$ & & & \\
\hline & Statistic & df & Sig. & Statistic & df & Sig. & \\
\hline Nilai & .136 & 22 & .060 & .981 & 40 & .713 & \\
\hline
\end{tabular}


Tabel di atas merupakan hasil output SPSS.

Ada dua uji yang dilakukan, yaitu:

1. Kolmogrov Smirnov didapat bahwa pada kelas kontrol dan kelas eksperimen tingkat signifikansi atau nilai probabilitasnya di atas 0,05 yaitu 0,129 dan 0,060, maka dapat dikatakan normal

2. Shapiro Wilk, didapat tingkat signifikansi atau nilai probabilitasnya pada kelas kontrol dan kelas eksperimen di atas 0,05 yaitu 0,345 dan 0,713. Maka nilai berdistribusi normal

Tabel 4. Analisis Uji Normalitas Hasil Belajar Kelas Sampel

\begin{tabular}{|l|l|l|l|l|}
\hline Kelas & $\begin{array}{l}\text { Uji } \\
\text { Kolmogrof } \\
\text { Smirnof }\end{array}$ & $\begin{array}{l}\text { Uji } \\
\text { Shaphi- } \\
\text { ro Wilk }\end{array}$ & $\begin{array}{l}\text { Uji Q- } \\
\text { Q Plot }\end{array}$ & $\begin{array}{l}\text { Kesim- } \\
\text { pulan }\end{array}$ \\
\hline$X_{\text {IS1 }}$ & 0,129 & 0,345 & $\begin{array}{l}\text { Sekita } \\
\text { rgaris }\end{array}$ & Normal \\
\hline$X_{\text {IS2 }}$ & 0,85 & 0,532 & $\begin{array}{l}\text { Sekita } \\
\text { r garis }\end{array}$ & Normal \\
\hline
\end{tabular}

Berdasarkan analisis tersebut maka hasil belajar kelas $\mathrm{X}_{\mathrm{IS} 1}$ dan $\mathrm{X}_{\mathrm{IS} 2}$ adalah normal.

2. Uji Homogenitas Variansi

Pengujian ini bertujuan untuk melihat apakah kedua kelompok mempunyai variansi yang homogen atau tidak.

Uji homogenitas variansi populasi bisa dilakukan dengan menggunakan bantuan SPSS.

\section{Tabel 5. Test of Homogeneity of Variances}

\begin{tabular}{|c|c|c|c|}
\hline Levene Statistic & $\mathrm{df1}$ & $\mathrm{Df} 2$ & Sig. \\
\hline 2.784 & 1 & 75 & .099 \\
\hline
\end{tabular}

Keputusan pada kolom Test of homogeneity of variances dapat dilihat probabilitasnya 0,099 lebih besar dari 0,05 sehingga $H_{0}$ diterima, artinya bahwa kedua kelas homogen.

Dari hasil analisis uji normalitas, homogenitas hasil belajar kelas $\mathrm{X}_{\mathrm{IS} 2}$ yang merupakan kelas eksperimen dan kelas $\mathrm{X}_{\mathrm{IS} 1}$ merupakan kelas kontrol disimpulkan bawa distribusi hasil belajar kedua kelas tersebut normal dan homogen seperti yang terdapat pada tabel berikut.

Tabel 6. Analisis Uji Normalitas dan Homogenitas Kelas $\mathrm{X}_{\mathrm{IS} 1}$ dan $\mathrm{X}_{\mathrm{IS} 2}$

\begin{tabular}{|c|c|c|}
\hline Kelas & Normalitas & Homogenitas \\
\hline $\mathrm{X}_{\mathrm{IS} 1}$ & Normal & Homogen \\
\hline $\mathrm{X}_{\mathrm{IS} 2}$ & Normal & Homogen \\
\hline
\end{tabular}

\section{Uji Hipotesis}

Perhitungan hasil uji hipotesis dapat dilihat pada tabel berikut

\section{Tabel 7. Analisis Uji Hipotesis}

\begin{tabular}{|c|c|c|c|c|}
\hline Kelas & $\begin{array}{l}\text { Taraf } \\
\text { Keperc } \\
\text { a-yaan }\end{array}$ & $\mathrm{t}_{\text {hitung }}$ & $\mathrm{t}_{\text {tabel }}$ & $\begin{array}{l}\text { Keputusan } \\
\text { Hipotesis }\end{array}$ \\
\cline { 1 - 4 } Eksperimen & $95 \%$ & 1,82 & 1,67 & $\mathrm{H}_{0}$ ditolak \\
\cline { 1 - 3 } Kontrol & & &
\end{tabular}

Berdasarkan analisis uji-t yang diperlihatkan pada tabel di atas maka diperoleh nilai t(hitung) adalah 1,82 sedangkan t(tabel) dengan taraf kepercayaan 95\% adalah $\mathrm{t}_{(0,95)}=1,67$, karena $\mathrm{t}_{\text {hitung }}>\mathrm{t}_{\text {tabel }}$ maka hipotesis $\mathrm{H}_{0}$ ditolak sehingga dapat disimpulkan bahwa hasil belajar matematika yang 
pembelajarannya mengunakan strategi active learning dengan cara giving questions and getting answers lebih baik dari hasil belajar matematika siswa yang menggunakan pembelajaran konvensional.

Jika kita bandingkan ketuntasan belajar siswa sebelum dan sesudah penelitian, maka tampak jelas bahwa ketuntasan belajar siswa sebelum penelitian lebih rendah daripada sesudah penelitian.

Selain itu, hasil analisis skor tes akhir siswa terlihat bahwa hasil belajar matematika kelas eksperimen lebih baik dari hasil belajar matematika kelas kontrol. Hal ini dapat dilihat pada rata-rata dan nilai terendah kelas eksperimen lebih tinggi dari kelas kontrol, walaupun nilai tertinggi kedua kelas adalah sama yaitu 100, nilai terendah kelas eksperimen adalah 65, rata-ratanya dan simpangan bukunya adalah 8,49. Sedangkan pada kelas kontrol nilai terendah adalah 52, rata-ratanya 77,65 dan simpangan bukunya adalah 10,79. Artinya hasil belajar kelas eksperimen memiliki keragaman yang lebih kecil dari kelas kontrol.

Selain melihat perbandingan nilai terendah, rata-rata dan simpangan buku kelas sampel mengenai hasil belajar matematika siswa, maka dilakukan uji-t untuk menguji hipotesis yang dirumuskan. Berdasarkan hasil analisis uji- $\mathrm{t}$ diperoleh $\mathrm{t}_{\text {hitung }}=1,82$, sedangkan $\mathrm{t}$ tabel dengan taraf kepercayaan 95\% adalah $\mathrm{t}$
${ }_{(0,95)}=1,667$, karena $\mathrm{t}_{\text {hitung }}>\mathrm{t}_{(1-\alpha)}$ sehingga hipotesis dalam penelitian ini berbunyi "Hasil belajar matematika siswa mengunakan strategi active learning dengan cara giving questions and getting answers lebih baik daripada menggunakan pembelajaran konvensional" diterima.

Jadi, berdasarkan hasil belajar yang diperoleh siswa dapat dinyatakan bahwa Hasil belajar matematika siswa mengunakan strategi active learning dengan cara giving questions and getting answers lebih baik daripada menggunakan pembelajaran konvensional.

Apabila ditinjau dari tes akhir, pada kelas eksperimen jumlah siswa yang telah mencapai nilai lebih dari atau sama dengan 76 sebanyak 17 orang dari 22 orang, sedangkan pada kelas kontrol sebanyak 14 orang dari 22 orang. Hal ini menunjukkan pada kelas eksperimen terdapat 17 orang siswa yang telah tuntas belajarnya secara individual, sedangkan pada kelas kontrol juga 14 orang siswa. Data tersebut juga menunjukkan bahwa penguasaan materi, baik kelas eksperimen maupun kelas kontrol masih rendah karena kurang dari $85 \%$ siswa yang memperoleh nilai di atas 76 .

Walaupun penguasaan materi siswa masih rendah tetapi hasil belajar matematika kelas eksperimen yang menggunakan mengunakan strategi active learning dengan cara giving questions and getting answers lebih 
baik dari pada hasil belajar matematika kelas kontrol yang menggunakan pembelajaran konvensional. Ini berarti penerapan model pembelajaran active learning dengan cara giving questions and getting answers cukup efektif. Jadi, dapat disimpulkan penerapan model pembelajaran active learning dengan cara giving questions and getting answers dapat meningkatkan hasil belajar matematika siswa.

\section{SIMPULAN DAN SARAN}

\section{Simpulan}

Bertitik tolak dari analisa yang dilakukan dalam penelitian ini maka dapat ditarik kesimpulan bahwa: "hasil belajar matematika dengan menggunakan strategi active learning dengan cara giving questions and getting answers lebih baik daripada menggunakan pembelajaran konvensional”.

\section{Saran}

Berdasarkan kesimpulan di atas, maka saran yang dapat diberikan penulis sebagai berikut:

1. Hendaknya bervariasi strategi yang digunakan dalam proses pembelajaran matematika sehingga siswa tidak merasa bosan ketika proses pembelajaran berlangsung.

2. Guru matematika diharapkan dapat menggunakan strategi active learning dengan cara giving questions and getting answers dalam pembelajaran matematika agar memperoleh hasil belajar yang baik.

3. Sebagai calon guru (kususnya penulis) diharapkan mampu menerapkan stategi active learning dalam proses belajar mengajar lebi maksimal lagi.

4. Kepada peneliti baru yang tertarik terhadap strategi pembelajaran ini, diharapkan melakukan penelitian lebih lanjut dan dapat mengembangkannnya pada pokok pembahasan yang berbeda.

\section{REFERENSI}

Al-Qur'an dan Terjemahnya

Ahmad, Abu. Dkk. (1991). Ilmu Pendidikan. Jakarta : Rineka Cipta.

Arief, Armai. (2002). Pengantar ilmu dan metodologi pendidikan islam. Jakarta : Ciputat Pres.

Arikunto, Suharsimi. (1997). Prosedur Penelitian Suatu Pendekatan Praktek. Jakarta Rineka Cipta.

Djamarah, Syaiful. (2000). Guru dan Anak Didik dalam Interaksi Edukatif. Jakarta : Rineka Cipta.

Djamarah, dan Bahri, Syaiful. (2002). Psikologi Belajar. Jakarta: Rineka Cipta

Hamalik Oemar. (2001). Pendekatan Baru Strategi Belajar Mengajar Berdasarkan CBSA. Bandung: Sinar Baru Algesindo.

Hasibuan Dan Moedjiono. (1985). Proses Belajar Mengajar. Bandung: PT. Remaja Rosdakarya.

Margono. (1996). Metodologi Penelitian Pendidikan. Semarang : Rineka Cipta 
Pramironegoro. 1985. Evaluasi Hasil Belajar Khusus Analisis Soal untuk Bidang Studi Matematika. Jakarta : PPLPTK.

Santoso, Singgih. 2001. SPSS. Jakarta : Gramedia.

Sardiman A.M.1999. Interaksi dan Motivasi Belajar Mengajar. Jakarta : PT. Raja Gravindo Persada.

Semiawan C, dkk. 1992. Pendekatan Keterampilan Proses. Jakarta : Gramedia

Silberman, Melvin L. 2006. Active Learning.101 Cara Belajar Siswa Aktif. Bandung: Nusamedia.

Slameto, 1995. Belajar dan Faktor-Faktor yang Mempengaruhinya. Jakarta : Rineka Cipta.
Sudjana, Nana.1989.Dasar-Dasar Proses Belajar Mengajar. Bandung : Sinar Baru Algesindo Offset.

Sudjana. 2001. Metoda Statistika. Bandung: Tarsito.

Suryabrata, Sumadi. 2003. Metodologi Penelitian. Jakarta : Grafindo.

Undang-Undang Sistem Pendidikan Nasional ( UU RI NO.20 TH.2003). Jakarta : Sinar Grafika.

Walpole, Ronald E. 1995. Pengantar Statistika. Jakarta : PT Gramedia pustaka Utama.

Winkel W. S. 1996. Psikologi Pembelajaran. Jakarta : Grasindo

Zaini, Hisyam, dkk. 2005. Strategi Pembelajaran Aktif. Yogyakarta : Nuansa Aksara Grafika. 